\title{
ONLINE LITERARY TEXT USAGE ON THE STUDENTS' READING COMPREHENSION
}

\author{
Rudi Permadi \\ STAI TASIKMALAYA \\ permadi83@yahoo.com
}

\begin{abstract}
Recently, the upcoming era, namely industry revolution 4.0 becomes trend topic and big issues. It has many roles in aspects of life. It can be recognized in teaching and learning process also. English practitioners, both teachers and students, should involve and master technology to improve their English capability or skills as the consequently. The research plays technology as a message of industry revolution 4.0 to encounter English teaching problem. The objective of the research is to find the effect of online literary text usage on the students' reading comprehension. The research methodology is using experiment with a factorial design. Data collection is obtained by examining reading comprehension test. One paired sample t-test acts to analyze the data. The number of sample is 40 students of 50 population number at Islamic studies program Sekolah Tinggi Agama Islam academic year 2017/2018. Random sampling works as technique of taking the sample. Data calculation and analysis shows that Asymp. Sig. (2-tailed) $=0.000$ less than Asymp. Sig. (2tailed) $<0.05$ explaining that $\mathrm{H}_{0}$ is rejected. It means that there is a significant effect of online literary text on the students' reading comprehension. Seeing the research result, it is suggested to English practitioners, both teachers and students, keep in touch online literary text to improve the students' reading comprehension.
\end{abstract}

Keywords: literary text, reading comprehension, teaching reading

\section{INTRODUCTION}

Enrolling of Industry Revolution 4.0 era, people must have some progress in their various aspects of life, mainly in education. It lets people to survive and reach their goal. The education and language has strong relationship for language skills assist educational success. Furthermore, Language supports one to do communication with others. English plays as means of communication among people around the world applied to do business, to get technology goals, education purpose, to improve cultural and science, so forth. Moreover, English competence has great role in career development, so students need to emboss their English in conquering industry revolution 4.0 era. Ghufron as quoted by Rohida (2018: 114) stated "University or organization or personal can get through in Industry Revolution 4.0 era if they act 4C. First, Critical Thinking, we should act skeptic and critics. Second, Creativity, meaning that people must be able to create new innovation and inventions. Next, Communication, mainly in science and technology aiming at leading people to go public and avoid misleading. The last, 
Collaboration, this is the power that can keep people in touch with relationship and understanding each other"

English can be mastered by several ways of teaching, but it has some obstacle. One of the main problems in learning English in formal education at university today is not learnt well by the students as if English is still regarded by frightening factor. Evidently, it can be seen by the result of the students' learn, they cannot master English well. This accomplishment of course, teaching learning activities are still using conventional, so it does not touch the students' need. It means learning the language is still dominated by the teacher centered and does not provide the access for students to develop independently. In many curriculum documents, the teacher needs to encourage the students to develop their students' skill in English.

Reading is concerning in this research because the experience states that the students' reading comprehension stand in low condition. He thinks that to answer this unsatisfactory output of reading, the education stakeholders, lecturers and students, should take a look at several possible factors. Such factors like lecturer's factor (the teaching approach, method, technique, the use of visual aids, and so forth), students' factor (motivation, willingness), relevant curriculum, and any other facilities must work together in affecting the final result of teaching.

They are some factors affected the bad result of reading comprehension based on the writer analyzes in teaching and learning process, as follows: 1 . The lecturer is using conventional method, 2. The students have no strong habit in literacy willingness, 3. Reading is a boring circumstances for some students. To encounter the obstacle, the lecturer observes the usage of online literary text.

The online literary text is one of up to date teaching media. It can be done by using computer technology as one of industry revolution 4.0 pillars. The students do not only learn it by lecturers' guidance, but also they still can learn it everywhere. This is because online literacy text is sustainable teaching media. The students just open the sites containing literacy text and read it, even read and listen it.

The online literacy text used in this research is short story. The students are engaged to get short stories in the computer. They are reading the text and even some can be read and listened also because the speaker reads the text given. Those notions above makes the writer to formulate the problem as follows: Is there any effect of online literary text on the students' reading comprehension at second semester of Islamic study program STAI Tasikmalaya academic year 2017/2018? The objective of the research is to know the effect of online literary text on the students' reading comprehension at second semester of Islamic study program STAI Tasikmalaya academic year 2017/2018

\section{Online Literary Text}

Literary text means literatures served digitally. It can be prose, fiction, poem, short story, novel and so forth. They all are cheap and easy. The people do not need money to buy all the literatures mentioned. It can be accessed through either by the smart phone or computer easily. Considering on the effective of technology and people need in improving language skills, online literature, particularly short story can be as a teaching media. The usage of short story as online literary text is really needed recently in learning reading. It will improve 
student's willingness, motivation, stimulus and even influencing strategy to the students. The teaching and learning will attract the students, so it will increase the student's motivation in learning. In addition, the material will be clearer. It is easy to be understood by the students. Besides, the method of teaching will be vary. It is not verbal communication occur in the class, so the student will not boring. Moreover, the students will do more activities in the teaching and learning process. It has the students to observe, do, act, analyze, and others.

Short story online helps the students to learn the four language skills; those are listening, speaking, reading, and writing. Erkaya (2004: 1) stated some instructors may still believe that teaching EFL encompasses focusing on linguistic benefits only, so eventually their students will communicate in the target language and the others who have integrated literature in the curricula have realized that literature adds a new dimension to the teaching of EFL. Short stories, for example, help the students to learn the four language skills (listening, speaking, reading, and writing) more effectively because of the motivational benefit embedded in the stories. In addition, with short stories instructors can teach literary, cultural, and higher order thinking aspects. It means that teaching by using short story as online literary text has many functions and more effective. It helps the students to master the four language skills (listening, speaking, reading, and writing) easily.

\section{Reading Comprehension}

Reading definitions described in this paragraph. Albert and Sipay (1977: 7) states "Reading is a very complex process in which the recognition and comprehension of written symbols are influenced by the perceptual skills, the decoding skills, the experience, the language background, the mind set and the reasoning ability of reader, as he anticipates meaning on the basis of what he has just read" Furthermore, Nuttal (1996: 11) assumes that "reading is an interactive process" According to Grabe and L Stoller (2002: 18) point out "Reading is also interactive in the sense that linguistic information from the text interacts with information activated by the reader from long-term memory, as background knowledge. Reading involves an active search for information and interaction with the text. It requires the constant constructive involvement of the reader in what he is doing. It requires the use of high level mental abilities and background knowledge" Next statement of reading coming from Nunan (1991: 72) "Reading is usually conceived of as solitary activity in which the reader interacts with the text isolation."

Speaking of reading comprehension, the first thing that should be explained is the definitions of comprehension since the primary goal of reading, which is comprehension. Comprehension is a term which is directly related to the ability of the readers to understand a passage and it involves thinking. As a result, higher levels of comprehension would obviously include higher levels of thinking (Dorothy, 1982: 107).

Comprehension is a process that requires the translation of written language into a form that is usable by the reader's cognitive system. It requires the integration of that information into the network of existing knowledge stored in the reader's long-term memory system. It can be described that the 
comprehension process fully would also have to deal with many different types of information that may be available and useful to the cognitive system during reading. In addition, comprehension is the process of getting meaning from a page. It is viewed here as an interactive process of bringing meaning a text as well as getting meaning from the text.

Meanwhile, Southgate (1972: 102) makes a summary about comprehension. She summarizes that comprehension is based on the reader having an adequate decoding system. Comprehension includes that the book says (literal), what the book really means (interpretive), how good the book is (evaluative), how the book makes him feel (reactive) and finally, what the book means on him (integrative). When the reader takes a book for his own, he makes it fit and puts it on; so that what started out as printed tracks on a page ends up as a moving force for humanity and contributes to the ultimate meaning an individual may find in his life. This is the goal that teachers are trying to reach; and in so doing they also enhance and enrich their own life.

Comprehension involves more than reading an author's syntactically correct, semantically plausible sentence or passage. The generation of literal or inferential meanings for written language involves the readers active construction of verbal imagination and related to representations for the text, using knowledge experience and context procedures or enhances the understanding that comprise reading comprehension. Reading comprehension, furthermore, is a complex intellectual process involving a number of abilities. The two major abilities involve word meanings and reasoning with verbal concepts (Dorothy, 1982: 107). This means that reading comprehension is a process of constructing meaning from a text and an active thinking process.

Reading comprehension involves different people and contexts, the psychological process involved in generating meaning by relating to the parts of the text to one another and store information such as rules, schemata and memories of events. Johnson and Pearson (1978: 8) point out that reading comprehension seems to involve language, motivation, perception, concept and development in the whole of experience itself.

From the definitions elaborated previously, it can be concluded that reading comprehension is a complex intellectual process related to multiple numbers of skills and abilities that are interrelated and interdependent. In this case, the students can master reading if they comprehend the texts they read or vice versa. To make the students grasp the meaning from the texts, they should read the texts repeatedly until they do comprehend with the written messages from the author.

\section{The online short story as a literary text and its benefit in reading comprehension}

The short story is a kind of literature. It can be found by online. It is a printed material made by people, thinker, researcher, literary worker, scholars etc. Short story usually tells us about many kinds of aspect of life, such as social aspect, legend, life meaning, history, culture, religion, philosophy and region. The short story is a literary genre. The short story is a literary genre of narrative 
fictional prose and no longer than novel like novellas and novels. It means that short story is a literary genre that is not too long.

Short story is a short fictional prose. Short story is a prose tale which has short volume of page. Ghasemi and Hajizadeh (2011: 69) state "The short story is a compact literary genre in which much is left unsaid in order for the reader to draw implication." The short story is a literary that can be valuable of the language skills development. Ghasemi and Hajizadeh (2011: 69) state "The short story as a multi-dimensional literary genre can be profitably used in the acquisition of various language skills. The short story's distinctive feature's i.e. its brevity, modernity, and variety make it appealing and interesting to language learners."

From the definitions above, the writer concludes that short story is a fictional prose and it can be categorized as a literature tends to be more concise and to the point than longer works of fiction such as novellas (in the modern sense of the term) and novels. The short story is really short to be published as a volume on its own, as novellas sometimes and novels usually are but the short story as a multi-dimensional literary genre can be profitably used in the acquisition of various language skills. The short story's distinctive feature's i.e. its brevity, modernity, and variety make it appealing and interesting to language learners.

There are two kinds of teaching media, those are electronic media and simple media. The characteristic of simple media is easy to make, to get, and to use. The short story as online literary text is electronic media because it can be accessed digitally as the model of learning faced industry revolution 4.0. The researcher believes that short story as one of the online literary texts can be teaching media. It helps the students to get the knowledge, concepts, and theories through using short story. Furthermore, it can develop the students' motivation in learning something. Therefore, the writer concludes that short story is a teaching media.

Online short story is a teaching that can be practiced everywhere. Reading short story is a suggested way to be done in the classroom. Collie and Slater (1995: 1) states "Reading stories in a classroom first, rather than in armchair. Working with other people in groups gives you a lot of advantages: it can help each other with the difficulties, and can share ideas, reactions, and interpretation." Reading comprehension, as a fundamental language skill, requires a complex acquisition process which can account for the way that the learners comprehend what they read. Some materials such as textbook are needed to enhance reading comprehension, such as word analysis, structural analysis, dictionary use, and learning the meaning of words from the context. Short stories could be beneficial since literature has the quality of being universal and short stories will allow the teacher to deal with human problem.

Pourkalhor and Kohan (2013: 1) states the following advantages for pedagogical advantages of short stories over other literary texts:

1. Short stories makes the students' reading task easier because it is simple and short Give learners a better view of other people and other cultures

2. It Requires more attention and analysis helps students to be more creative and

3. It raises cultural awareness

4. It reduces students anxiety and helps them feel more relax 
5. It is good for multicultural contexts because of its universal language

6. It offers a fictional and interesting world.

The teaching and learning process by using short story will increase the students' reading comprehension. According to Erkaya (2004: 1) "The results of a comparison between a group of students that read literary texts and a second group that read non-literary texts at a university in Hong Kong is the group who read literary texts showed improvement in vocabulary and reading comprehension." It means that the students who use literary text is better than the students who do not use it. Ghasemi and Hajizadeh (2011: 69) state "Many ESL/EFL experts agree that the content knowledge is an important factor in the learning process of reading comprehension. The short story distinctive features, i.e., its brevity, modernity, and variety make it appealing and interesting to language learners and a value source for the improvement of language learning reading comprehension. The short story can offer learners adequate linguistic, intellectual, and emotional involvement and enrich their learning experience."

Furthermore, Ghasemi and Hajizadeh (2011: 69) state "A good number of ESL/EFL experts do agree that content knowledge is an important factor in the learning process of reading comprehension. A valuable source of knowledge is, undoubtedly, literary texts, and more appropriately and for reading comprehension process, the short story. Using the short story to enhance students' reading proficiency has another privilege. The short story is a compact literary genre in which much is left unsaid in order for the reader to draw implication. Therefore, it makes students sensitive to the hidden and implied meaning."

\section{Teaching Reading by Using Online Short Story as a Literary Text}

Many techniques has been implemented to teach reading, one of these is by using online short story as literary text. Pourkalhor and Kohan (2013: 1) state "Reading is not just a single skill but a combination of many skills and processes in which the readers interact with printed words and texts for content and pleasure. Through reading, one can teach writing, speaking, vocabulary items, grammar, spelling and other language aspects. There are some essential goals of reading such as enabling the students to understand the world, growing their interest, and finding solution to their own problems. The use of literature as a technique for teaching both basic language skills (i.e. reading, writing, listening and speaking) and language areas (i.e. vocabulary, grammar and pronunciation) is very popular within the field of foreign language learning and teaching nowadays. Moreover, in translation courses, many language teachers make their students translate literary texts like drama, poetry courses, and short story into their mother language." In addition, four steps to teach reading, 1. Introducing the text, 2. Reading the text, 3. Exploring the text, 4. Responding the text (E. Tompkins and Hoskisson, (1991: 268-270). The teacher should also guide the students to translate, pronounce, and understand the word. E. Mayer (2003: 34) conveyed "Learning to read involves learning how to translate printed words into another form, such as pronouncing and understanding the words"

Online Short story has valuable benefit if it is chosen in the development in language skills, particularly in reading comprehension. Ghasemi and Hajizadeh (2011: 70) state "When the short story is chosen based on the student's level of English proficiency, it can offer them adequate linguistic, intellectual, and 
emotional involvement and enrich their learning experience. The short story can provide ESL/EFL learners with a suitable study resource which is both delightful and instructive to improve their English linguistics proficiency and reading comprehension"

There are five main parts of short story. They are theme, character, setting, plot, and conflict.

1. Theme

The theme is the foundation or the point of the story, sometimes can be even said the core of what the writer is thinking. It is not written explicitly, but it can be figure out by reading and comprehending the story. It can be social theme, level of ego theme, organic theme, divine theme, and physic theme.

2. Character

A character means someone habit or even not people term, it can such animal, who has role in the story. They have their own unique to play and involve in the short story as literary text.

3. Setting

The setting represents the time, place, weather condition, social condition, mood or atmosphere of the story. It lets the story become more attractive, readable, easy to comprehend, and having interactive or interrelationship, even engaging between reader and writer.

4. Plot

A plot rules how one incident has connection with another incident. It can be named also the sequence of the story arranged as a series occurs in whole fictions events.

5. Conflict

The conflict defines as the character opposition disagreeable. It rises when the character has different goal with the other. They fight to stand their own principles. The writer concludes that the main parts of short story are theme, character, setting, plot, and conflict. The writer assumes if the students regularly read by identifying the elements of the online short story, it will influence into their reading comprehension.

In the learning reading process, the student should get the students to read short story first online. The next, they are led to identify the theme, character, setting, plot, and conflict. After they succeed to label all the elements of the short story, the teacher should explain the function why they must know them. Knowing the theme of the online short story, it will help the students easy to find out the main idea on the passages subsequently. In addition, they can categorize what types of main ideas available on the text.

By labeling the characters on the online short story, the students will easy to find out to the existing characters on the passages. In addition, the student can be able to find out how the character's physical/appearance on the passages easily. Moreover, the student is easy to find out what the character's say, think, feel, do or does on the passages. This step will drive the students to decide the supporting ideas on the passages.

The next step of teaching reading by using online short story based on the writer's opinion is identifying setting on the short story. This will assist the 
students easy to naming the places available on the passages. The next, it helps the student easy to identify the time available on the passages. The last, the students think easy to identify the conditions available on the passages. This benefit of this activity is the same as labeling the character. It incubates the students think easy to decide the supporting ideas on the passages. Comprehending the plot and the conflict on online short story has some functions. It will make the student understand the genres, the generic structures in passages, the structure and grammar on the passages, the tenses, the moral value, the meaning, comprehend the passages served.

\section{METHOD}

\section{Population and Sample}

Population is group which is being surveyed. Sanders (1976: 117) stated "Population is the total of any kind of unit under consideration by the analyst" Furthermore, Sudjana and Ibrahim (2010: 84) state "The term population has connection with the elements that are units where the data obtained. The elements can be individual, family, household, social group, school, class, organization, and so forth. In other words, population is group of some numerous element" The population in this research is the students at second grade Islamic studies program STAI Tasikmalaya Academic Year 2017/2018 consisting 50 students. The sample defines as part of group which is being surveyed. The sample in this group contains 40 students. They experienced teaching with no using online short story first and then also teaching with using online short story.

\section{Research Method}

The method used in this research is experiment with a factorial design. It is used to find the particular effect of treatment (Sugiyono, 2010: 13). Online short story applied in teaching and learning process after they have not conducted teaching with online short story first.

\section{Variables}

Variables are the concepts that stand in one class or one particular object. Fraenkel and Norman (2003: 41) convinced "Variable is a concept or a noun that stands for variation within a class of object" The variables of the research consist of:

1. Independent Variable, online literary text (online short story (X)

2. Dependent Variable, the students' reading comprehension (Y)

\section{Research Instrument}

The instrument of the research is a test. Brown (2004: 3) defines "Test as a method of measuring a person's ability, knowledge, or performance in a given domain." The test is a multiple choice to measure the skill of the students' reading comprehension. It is the simplest way to conduct and the most effective way in collecting the data obtained. The clues of reading comprehension test cover some skills, such as student is able to find out the idea of the text, student is able to comprehend the passages served, student is able to collect, interpret, apply, 
analyze, and synthesize the information, and student is able to find out and describe the specific information.

\section{Research Design}

Research design means a blue print, a guideline to researcher to understand the relationship point between variable observed (Anggoro, 2007: 17). Research design is using one-group pretest-posttest design, the picture is as follows:

$$
\mathrm{O}_{1} \times \mathrm{O}_{2}
$$

Picture 1: Researh Design

Notes :

$\mathrm{O}_{1}=$ pretest score

$\mathrm{O}_{2}=$ post test score

$\times=$ treatment

\section{Technique of Collecting and Analyzing Data}

The primary data of the research is reading comprehension multiple choice test. All the questions have been examined beforehand for getting the validity and reliability rules. After the data obtained and calculated by using SPPS 20, there are 7 items of test which are invalid. Those items above were not examined in posttest step. Furthermore, the result of reliability calculation is 0.71 . It means that the items of test are reliable because it is more than 0.6. This number shows that the test can be used as the reading comprehension instrument for the research. The following figure is the detail of the result:

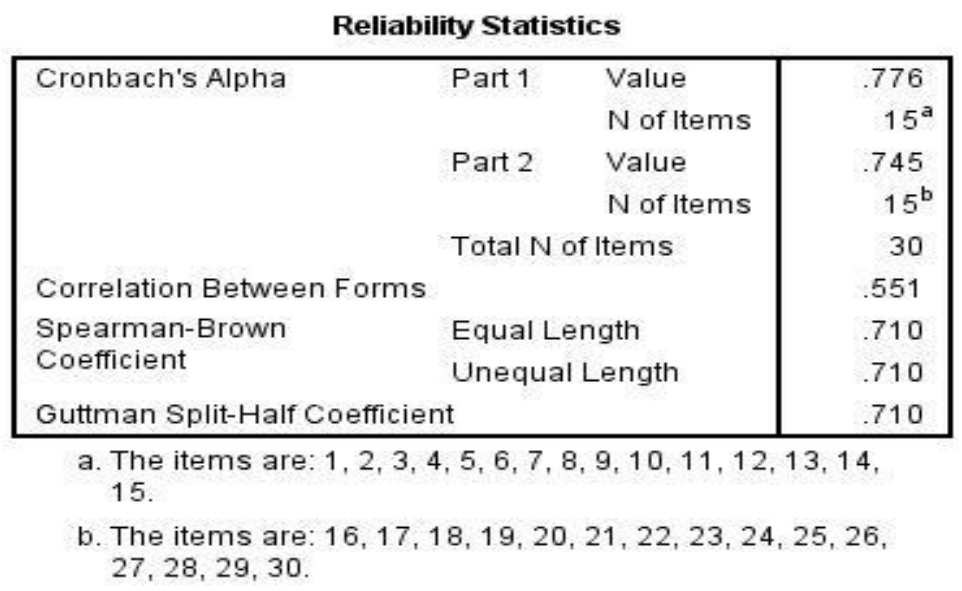

Diagram 1: Reliability of reading comprehension

The research aims at analyzing the difference of score rate between pre-test and post-test in one sample, therefore he uses one paired sample t test to analyze the data. 


\section{FINDINGS AND DISCUSSION}

\section{Findings}

\section{a. Normality Test}

This test is to measure whether the data distribution normal or not. The following is the result of normality test of students' reading comprehension

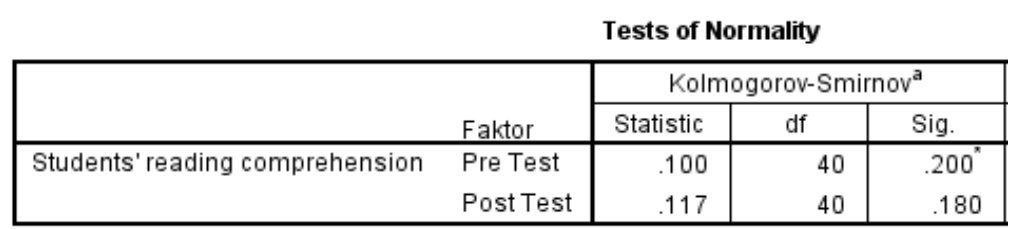

*. This is a lower bound of the true significance.

a. Lilliefors Significance Correction

Diagram 2: Normality Test

Based on the data result on diagram 1, Kolmogorov-Sminov table shows that the significant level is 0.200 and 0.180 it can be summarized that the significance level both in pretest and posttest stand in normal because it is more than 0.05 .

\section{b. Homogeneity test}

This is to examine whether some of population variant is same or not. The following is the result of homogeneity test of students' reading comprehension

\section{Test of Homogeneity of Variances}

Students' reading comprehension

\begin{tabular}{|l|r|r|l|}
\hline $\begin{array}{l}\text { Levene } \\
\text { Statistic }\end{array}$ & df1 & df2 & Sig. \\
\hline 1.216 & 1 & 78 & .274 \\
\hline
\end{tabular}

Diagram 3: Homogeneity Test

Based on the data result on diagram 2, it stated 0.274 is more than 0.005 . it can be summarized that the significance level both in pretest and posttest stand in homogenous because it is more than 0.05 .

\section{c. Statistic Hypothesis Test}

The students' reading comprehension data analyzed by using paired sample t test which the calculation process helped by SPPSS version 21 for windows.

The following is the result of the computation

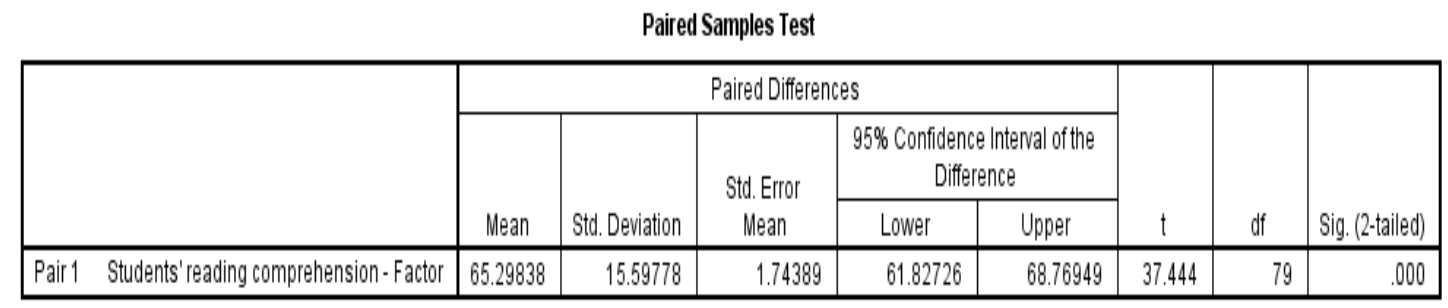

Diagram 4: Statistic hypothesis test 
By seeing diagram 3, it can be drawn the conclusion that there is significant effect of online literary text usage on students' reading comprehension. Hypothesis tested by seeing significant coefficient. If Sig. value $>0.05$ then $\mathrm{H}_{\mathrm{o}}$ accepted and $\mathrm{H}_{1}$ is refused. If Sig. value $<0.05$ then $\mathrm{H}_{1}$ accepted and $\mathrm{H}_{\mathrm{o}}$ is refused. Based on the table, the researcher gets the result of paired sample $t$ test with sig = $0.000<0.05$. Therefore, there is a significant effect of online literary text usage on the students' reading comprehension operationally, the students' reading comprehension is measured by objective test (multiple choices with five possible answer). Theoretically, it can be assumed that the students' reading comprehension is influenced by online short story as literary text.

The detail finding can be recognized by analyzing each blue print of reading comprehension. The first, the student is able to find out the idea of the text. The total average score before teaching using online short story is 0.6 , and after the students get literary text usage story is 1.31 .The data shows that the students is assisted by online literary text usage. They had improvement in finding out idea of the various texts because they experienced how to recognize the theme of online literary text.

The second, student is able to comprehend the passages served. Again, in this problem, online literary text gives positives contribution. The data shows that the total average score before treatment is 1.05 , and after treatment is 1.27 . They trained to comprehend the passages by analyzing and identifying setting on the short story. This will assist the students easy to naming the places available on the passages. The next, it helps the student easy to identify the time available on the passages. The last, the students think easy to identify the conditions available on the passages. This benefit of this activity is the same as labeling the character.

The third, student is able to collect, interpret, apply, analyze, and synthesize the information. The data obtained in this case shows that the total average score before treatment is 1.02 and after treatment is 1.06 . It is obviously that the online literary text has role in improving reading comprehension. The students are required to see detail in finding out how the character's physical/appearance on the passages easily. Moreover, the student is easy to find out what the character's say, think, feel, do or does on the passages.

The last, student is able to find out and describe the specific information either. The data shows that after treatment, the students obtained 0.8 total average score but before treatment is 0.6. In this atmosphere, the students are led to comprehend the plot and the conflict on online short story. It will make the student understand the genres, the generic structures in passages, the structure and grammar on the passages, the tenses, the moral value, the meaning, comprehend the passages served.

All findings above are supported and relevant with the research before. Ghasemi and Hajizadeh (2011: 69-70) states "When the short story is chosen based on the student's level of English proficiency, it can offer them adequate linguistic, intellectual, and emotional involvement and enrich their learning experience. The short story can provide ESL/EFL learners with a suitable study resource which is both delightful and instructive to improve their English linguistics proficiency and reading comprehension" 


\section{CONCLUSION AND SUGGESTION}

Based on the objective of the research and the data analysis, the writer is able to make conclusion that there is a significant effect of online literary text usage on the students' reading comprehension. It means that the online literary text truly gives positive contribution on the students comprehension particularly in such circumstances, as follows: student is able to find out the idea of the text, student is able to comprehend the passages served, student is able to collect, interpret, apply, analyze, and synthesize the information, and student is able to find out and describe the specific information. He has done the research in four treatments, because the English curriculum at research place focused on general English or English for specific purpose. It is not allowed to teach one skill in four meeting.

Seeing the research findings above, the writer suggests to English practitioners, both students and lecturers, to involve online literary text usage to improve their students' reading comprehension. Furthermore, it is allowed to further researcher, to get sustainable treatment in improving reading comprehension, not for four meeting only. The last, it is better to the stakeholder of research place to provide extra hours for the students to learn reading in many ways, such as multiple the numbers of English reading books, create stupendous reading spots, and keep in touch often times with the best regulation in improving English at all.

\section{REFERENCES}

Anggoro, etc. (2007). Research Method (Second 2). Jakarta: Universitas Terbuka Brown, H.D. (2004). Language Assessment: Principles and Classroom Practices. New York: Longman.

Collie, Joanne and Slater, Stephen. (1995). Short Stories for Creative Language Classroom. Great Britain: Cambridge University Press.

E. Mayer, Richard. (2003). Learning and Instruction. Ohio: Merril Prentice Hall.

E. Tompkins, Gail and Hoskisson, Kenneth. (1991). Language Arts Contents and Strategy. New York: Macmillan Publishing Company.

Fraenkel, Jack R and Norman. (2003). How to Design and Evaluate Research in Education. McGraw-Hill.

Ghasemi, Parvin and Hajizadeh, Rasool. (2011). Teaching L2Reading Comprehension through Short Story. Iran: Shiraz University.

Grabe, William and L Stoller, Fredricka. (2002). Teaching and Researching Reading. Longman: Pearson Education.

H. Sanders, Donald. (1990). Statistics: A Fresh Approach. Singapore. McGrawHill Book, Inc.

J Harris, Albert and R Sipay, Edward. (1975). How to Increase Reading Ability Sixth Edition. New York: David Mckay Company, Inc.

Johnson, D.D. and Pearson, P.D. (1978). Teaching Reading Comprehension. New York: Holt.

Nunan, David. (1991). Language Teaching Methodology. United Kingdom: Prentice Hall. 
Journal of English Teaching Adi Buana, Vol. 04 No. 01, April 2019

Nuttall, Christine. (1996). Teaching Reading Skills in a Foreign Language. Heinemann.

Pourkalhor, Omid and Kohan, Nasibeh. (2013). Teaching Reading Comprehension through Short Stories in Advanced Class. Iran: Department of English Islamic Azad University.

Rocha Erkaya, Odilea. (2004). Benefits of Using Short Story in the EFL Context. Turkey: Eskisehir Osmangazi University.

Rohida, Leni. (2018). The Effect of Industry Revolution Era on Human Reseources Competency. Bandung: Padjajaran University.

Rubin, Dorothy. (1982). A Practical Approach to Teaching Reading. New York: Holt Rinehart and Winston.

Southgate, Vera. (1972). Literacy at all levels. Manchester: Ward Lock Educational.

Sudjana, Nana and Ibrahim. (2010). Education Research and Assessment. Bandung: Sinar Baru Algesindo.

Sugiyono. (2010). Method of quantitative, qualitative, $R \& D$ research. Bandung: Alfabeta. 